\title{
Species Richness and Endemism of Zingiberaceae in Cinchona Forest Reserve, Lantapan, Bukidnon, Philippines
}

\author{
John Austin Lennox Faro Jayme ${ }^{1}$, Noe Polo Mendez ${ }^{2 *}$, Rainear Auxtero Mendez ${ }^{2}$, \\ Daniel F. Somera ${ }^{3}$, Alma B. Mohagan ${ }^{2,4}$ \\ ${ }^{1}$ Senior High School, Central Mindanao University, University Town, Musuan 8710 Bukidnon, Philippines \\ ${ }^{2}$ Center for Biodiversity Research and Extension in Mindanao (CEBREM), Central Mindanao University, \\ University Town, Musuan 8710 Bukidnon, Philippines \\ ${ }^{3}$ Protected Area Superintendent - Mt. Kitanglad Range Natural Park (MKRNP), Malaybalay City, Bukidnon, \\ Philippines \\ ${ }^{4}$ Department of Biology, College of Arts and Sciences, Central Mindanao University, University Town, Musuan \\ 8710 Bukidnon, Philippines
}

Article history:

Submission October 2019

Revised November 2019

Accepted April 2020

*Corresponding author:

E-mail: npolomendez@gmail.com

\begin{abstract}
This study was carried out to provide information on species richness and endemism of Zingiberaceae in Cinchona Forest Reserve, Kaatuan, Lantapan, Bukidnon, Philippines. Transect walks, opportunistic sampling and collection within the sampling quadrats were conducted along established forest trails to collect ginger species. A total of 11 species of Zingiberaceae were documented belonging to two subfamilies (Alpinioideae and Zingiberoideae) and three tribes (Alpinieae, Hedychieae, and Zingibereae). The species recorded include Adelmeria alpina Elmer, Alpinia haenkei C.Presl, A. rufa C.Presl, Etlingera fimbriobracteata (K.Schum.) R.M.Sm., E. pubimarginata (Elmer) A.D.Poulsen, Hedychium philippinense K.Schum., Hornstedtia conoidea Ridl., H. lophophora Ridl., Meistera muricarpa (Elmer) Škorničk. \& M.F.Newman, Zingiber banahaoense Mood \& Theilade, and Zingiber sp. Of these, H. philippinense is the only threatened species recorded. All species are endemic to the Philippines except for E. fimbriobracteata which is native to Borneo and Zingiber sp. which is unidentified to the species level. These species represent $41 \%$ of the total genera and $9 \%$ of the total species of Zingiberaceae in the Philippines. The high endemicity (82\%) in the total collected species in this study and the presence of a threatened species in this area calls for protection and conservation by the stakeholders.
\end{abstract}

Keywords: Etlingera pubimarginata, Gingers, Key Biodiversity Area, Hedychium philippinense, Philippine endemic

\section{Introduction}

Zingiberaceae is a monocot family and the largest among the 8 families in order Zingiberales. This family consists of at least 1,500 species which are distributed in 53 genera [1]. In the Philippines, Zingiberaceae has 17 genera and more than 100 species [2]. Members of this family serve as a significant natural resource that offers useful products, such as for food, spices and condiments, medicines, dyes, perfumes, and aesthetics to man [3]. Recently, several new species of Zingiberaceae $[4,5,6,7]$ and species which are new records to the Philippines and holds new locality records in the country $[7,8,9,10]$ have been described and reported. 


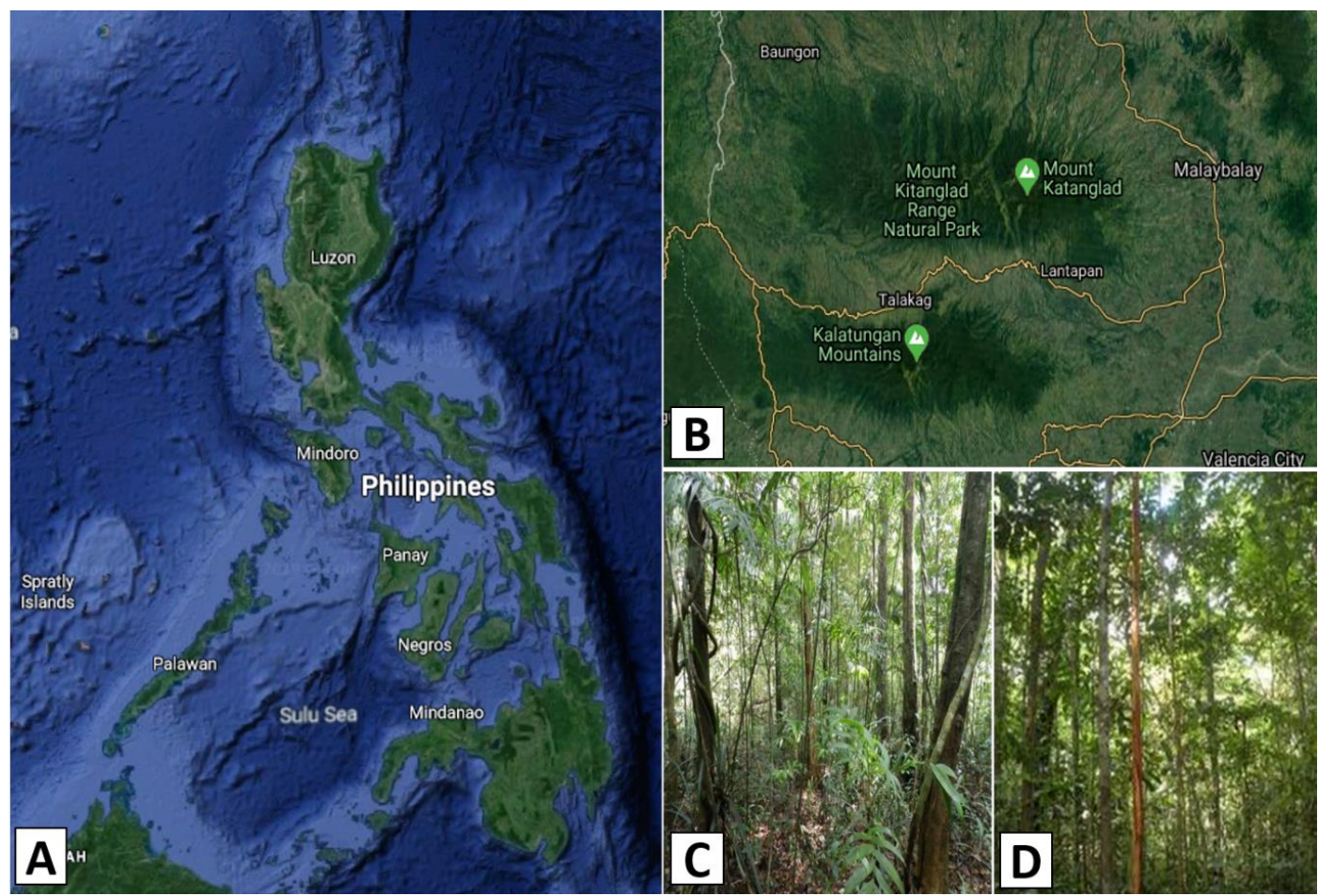

Figure 1. Study site. A) Map of the Philippines, B) Map of Bukidnon showing the location of the municipality of Lantapan, C and D) study areas where the plot sampling method was employed. A and B - (C) google map.

Zingiberaceae in the Philippines are mostly collected in Luzon Island, with the Visayas and Mindanao Islands ranking second and third, respectively [11]. The classification of Zingiberaceae continues to be refined $[12,13]$ and new taxa are still being discovered and described. Published reports on floristic studies of Philippine Zingiberaceae were recently conducted by Naive [14] at Mt. Nabukalan, Kalatungan Mountain Range in Bukidnon and Acero et al. [15] at the expansion site of Mt. Hamiguitan Range Wildlife Sanctuary (MHRWS) in Davao Oriental.

Cinchona Forest Reserve in Kaatuan, Lantapan, Bukidnon is located at the foot of Mt. Kitanglad Range Natural Park (MKRNP). It is home to the Cinchona Plantation established at Barangay Kaatuan and said to be the only one of its kind left in Asia and the Pacific. This present study was undertaken in Cinchona Forest Reserve to provide information on species richness and endemism of Zingiberaceae species.

\section{Material and Methods Entry protocol}

Prior Informed Consent (PIC) was secured from the local government unit (LGU), tribal lead- ers, and municipal mayor of the study site. The acquired consent, letter of recommendation, and the approved proposal were submitted to the Department of Environment and Natural Resources (DENR) to secure the Gratuitous Permit (GP) and Transport Permit (TP) as mandated in RA 9147 section 14 and section 15. The GP of ABM was used in this study.

\section{Selection of study site}

Floristic inventory of Zingiberaceae was carried out within the Cinchona Forest Reserve (Figure 1). Cinchona Forest Reserve is the area where the established 2-ha permanent plot of the Long Term Ecological Research (LTER) Site in Mt. Kitanglad is located. The sampling station is a rich plot due to its physical features, where sunlight is also humid allowing plants to spread more. The area has sufficient humidity to sustain developing and arboreal plants in its habitat.

\section{Establishment of sampling techniques}

Plot sampling was done through establishing three $20 \times 20 \mathrm{~m}$ plots. Each plot was bordered with lines making it near from each other. Meanwhile, transect walks were done in the established forest 
Table 1. Subfamilies, tribes and genera of the collected Zingiberaceae species

\begin{tabular}{|c|c|c|c|c|}
\hline No. & Subfamily & Tribe & Genus & No. of Species \\
\hline 1. & \multirow[t]{5}{*}{ Alpinioideae } & \multirow[t]{5}{*}{ Alpinieae } & Adelmeria & 1 \\
\hline 2. & & & Alpinia & 2 \\
\hline 3. & & & Etlingera & 2 \\
\hline 4. & & & Hornstedtia & 2 \\
\hline 5. & & & Meistera & 1 \\
\hline 6. & \multirow[t]{2}{*}{ Zingiberoideae } & Hedychieae & Hedychium & 1 \\
\hline 7. & & Zingibereae & Zingiber & 2 \\
\hline & & Total & & 11 \\
\hline
\end{tabular}

trails, while opportunistic sampling was done through searching and documenting of Zingiberaceae species outside the plot.

Subplot 10 is located at elevations ranging from 1,352-1,470 masl. The richness is visible to the quantity of plants' penetration which is normal, and is a quality forest. Subplot 20 is located at elevations of 1,476-1,489 masl. It is located just above the subplot 10 . Unlike subplot 10, this subplot is dry and shady which results to excessive discrimination of sunlight particularly for the plants on the ground. The area hosts quite a number of plants compared to the other subplots. Meanwhile, subplot 40 which is located at elevations of 1,425-1,402 masl was positioned downhill. Compared to the other two subplots, this subplot is dried and has not enough humid.

\section{Collection and processing of the specimens}

Collection of specimens was done during daytime. Other data of the species were recorded in a field notebook. To keep track of the gathered data, labeling and documentation of the areas and collected specimens were done. The specimens were placed in labeled cellophane bags and brought to the camp for further processing. The specimens were prepared following the wet method and were cut to fit in the mounting sheets. The pickled collections of the reproductive parts were placed inside labeled plastic containers.

\section{Identification of the specimens}

The specimens were identified using field guides, monographs, and published articles (e.g. $15,16,1,14,8,17)$. The specimens were morphologically described and compared with the specimens within the Philippines and neighboring countries.
Assessment of conservation status and endemism

The assessment of the conservation status was based from DAO 2017-11 [18], while endemism was based from Pelser et al. [2].

\section{Results and Discussions Species richness}

This study collected 11 species of Zingiberaceae belonging to two subfamilies (Alpinioideae and Zingiberoideae), three tribes (Alpinieae, Hedychieae, and Zingibereae) and seven genera (Table 1). The species include Adelmeria alpina Elmer, Alpinia haenkei C.Presl, A. rufa C.Presl, Etlingera fimbriobracteata (K.Schum.) R.M.Sm., E. pubimarginata (Elmer) A.D.Poulsen, Hedychium philippinense K.Schum., Hornstedtia conoidea Ridl., H. lophophora Ridl., Meistera muricarpa (Elmer) Škorničk. \& M.F.Newman, Zingiber banahaoense Mood \& Theilade, and Zingiber sp. (Figure 2; Table 2). Further, these species represent $41 \%$ of the total genera and $9 \%$ of the total species of Zingiberaceae in the Philippines.

The Alpinia, Etlingera, Hornstedtia and Zingiber obtained two species per genus, while Adelmeria, Meistera and Hedychium with one species per genus. Although plot sampling method was added in addition to transect walk and opportunistic sampling which were done in the previous floristic studies on Philippine Zingiberaceae by Naive [14] and Acero et al. [17], the collected species in this study were still lower compared to the species collected by Naive [14] at Mt. Nabukalan, Kalatungan Mountain Range in Bukidnon and Acero et al. [17] at Mt. Hamiguitan in Davao Oriental with 12 species and 14 species, respectively. Phenology and the size of area might be the reasons for the low species richness in Cinchona Forest Reserve. 

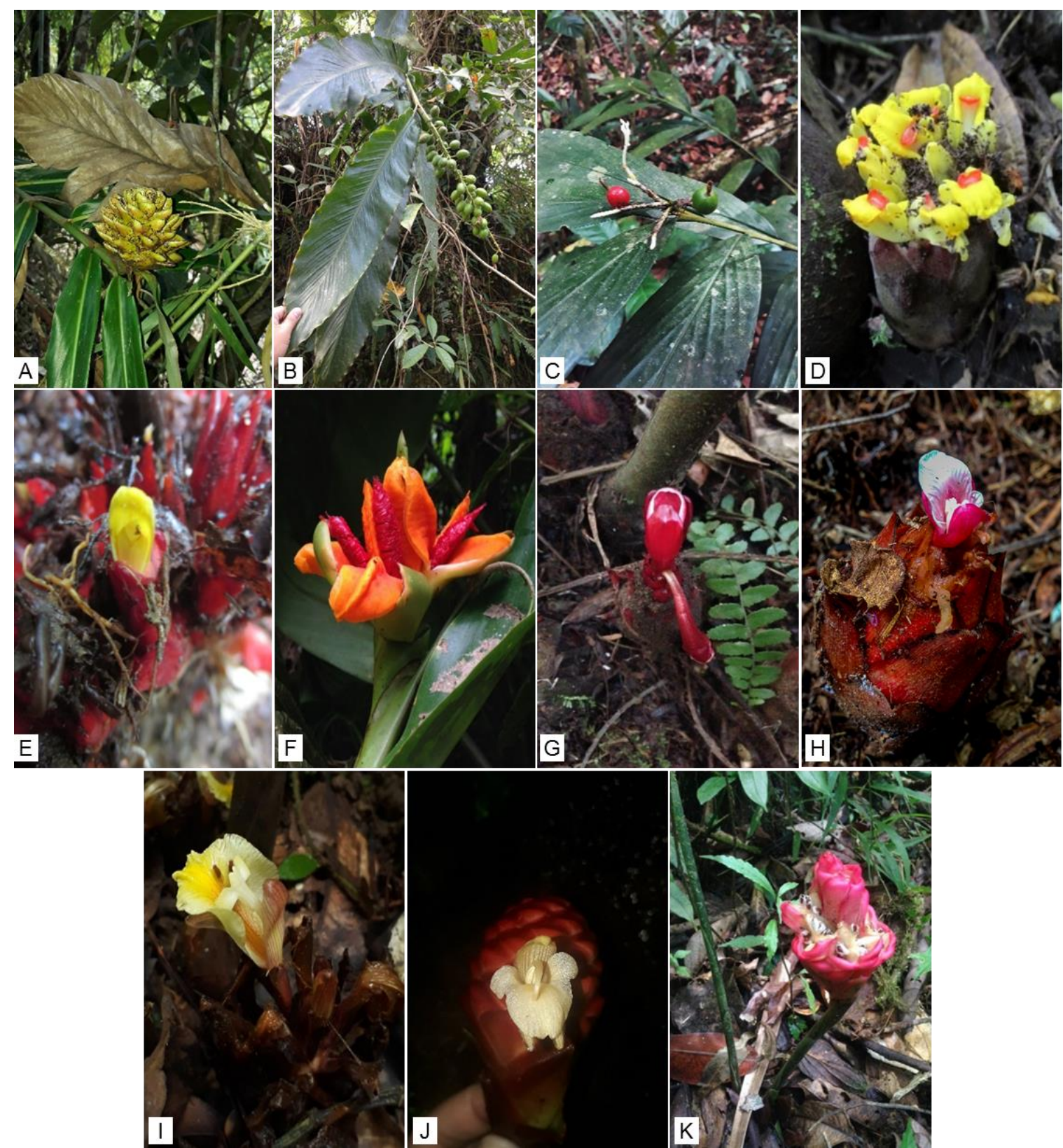

Table 2. Zingiberaceae species in Cinchona Forest Reserve. A) Adelmeria alpina Elmer, B) Alpinia haenkei C.Presl, C) Alpinia rufa C.Presl, D) Etlingera fimbriobracteata (K.Schum.) R.M.Sm., E) Etlingera pubimarginata (Elmer) A.D.Poulsen, F) Hedychium philippinense K.Schum., G) Hornstedtia conoidea Ridl., H) Hornstedtia lophophora Ridl., I) Meistera muricarpa (Elmer) Škorničk. \& M.F.Newman, J) Zingiber banahaoense Mood \& Theilade, and K) Zingiber sp. (Photos: A, C, I, J R.A. Mendez; B, D, E, F, G, H - N.P. Mendez; K - J.A.L.F. Jayme)

Recent reports on the occurrence of these collected species include A. alpina which has been reported by Naive [14] growing mostly at high elevations between 1,700 to 2,100 masl in deeply shaded localities on upper montane to mossy forests with humid environment at Kalatungan Mountain Range, while A. haenkei, A. rufa, $H$. conoidea and $M$. muricarpa have been reported by
Acero et al. [17] at Mt. Hamiguitan in Davao Oriental province. Further, $H$. philippinense was recently reported by Tobias et al. [9] from Kasibu, province of Nueva Vizcaya in northern Luzon and Mt. Malambo, Marilog District, Davao City in southern Mindanao and E. fimbriobracteata was also reported by Tobias et al. [9] at Marilog District in Davao City. 
Table 2. Species richness of Zingiberaceae in Cinchona Forest Reserve

\begin{tabular}{|c|c|c|c|c|c|}
\hline \multirow{2}{*}{ Species } & \multicolumn{3}{|c|}{ Subplot } & \multirow{2}{*}{$\begin{array}{c}\text { Transect } \\
\text { Walk }\end{array}$} & \multirow{2}{*}{$\begin{array}{l}\text { Opportunistic } \\
\text { Sampling }\end{array}$} \\
\hline & 10 & 20 & 40 & & \\
\hline Adelmeria alpina Elmer & - & - & - & - & / \\
\hline Alpinia haenkei C.Presl & - & - & - & - & / \\
\hline Alpinia rufa C.Presl & - & - & - & - & / \\
\hline Etlingera fimbriobracteata (K.Schum.) R.M.Sm. & - & - & - & - & / \\
\hline Etlingera pubimarginata (Elmer) A.D.Poulsen & - & - & - & - & / \\
\hline Hornstedtia conoidea Ridl. & - & - & - & / & - \\
\hline Hornstedtia lophophora Ridl. & - & - & - & / & / \\
\hline Meistera muricarpa (Elmer) Škorničk. \& M.F.Newman & - & / & / & - & - \\
\hline Hedychium philippinense K.Schum. & - & / & - & - & - \\
\hline Zingiber banahaoense Mood \& Theilade & / & - & - & - & - \\
\hline Zingiber sp. & - & - & - & - & / \\
\hline
\end{tabular}

Table 3. Conservation Status and Endemism of Zingiberaceae in Cinchona Forest Reserve.

\begin{tabular}{lcc}
\multicolumn{1}{c}{ Species } & Conservation Status [18] & Ecological Status \\
\hline Adelmeria alpina Elmer & - & Philippine Endemic \\
Alpinia haenkei C.Presl & - & Philippine Endemic \\
Alpinia rufa C.Presl & - & Philippine Endemic \\
Etlingera fimbriobracteata (K.Schum.) R.M.Sm. & - & Native to Borneo \\
Etlingera pubimarginata (Elmer) A.D.Poulsen & - & Philippine Endemic \\
Hornstedtia conoidea Ridl. & - & Philippine Endemic \\
Hornstedtia lophophora Ridl. & - & Philippine Endemic \\
Meistera muricarpa (Elmer) Škorničk. \& M.F.Newman & - & Philippine Endemic \\
Hedychium philippinense K.Schum. & Endangered & Philippine Endemic \\
Zingiber banahaoense Mood \& Theilade & - & Philippine Endemic \\
Zingiber sp. & - & - \\
\hline
\end{tabular}

Previously, the Philippine Zingiberaceae has 14 genera until de Boer [19] transferred most of the species of Philippine Amomum Roxb. to Meistera Giseke and Wurfbainia Giseke and Docot et al. [6] reinstated the Philippine endemic genus Adelmeria Elmer, making 17 genera in total. This is because Larsen et al. [15] reported that Zingiberaceae are still in an active stage of evolution. Also, Te-Lin \& Larsen [20] added that the relationships between several newly described species and genera are not yet fully understood. Thus, it is expected that several species of Zingiberaceae will be discovered and described in the Philippines as botanical expedition progresses.

\section{Conservation status and endemism}

Hedychium philippinense was the only threatened species collected in this study. The collected Zingiberaceae species revealed nine species (82\%) endemic to the Philippines, one non-endemic species (9\%) which is native to Borneo, and one species $(9 \%)$ which is unidentified to the species level (Table 3).

\section{Conclusion}

This study revealed 11 species of Zingiberaceae found in Cinchona Forest Reserve. Of these, 9 species are endemic to the Philippines, 1 species is native to Borneo, and 1 species is unidentified to the species level. $H$. philippinense is the only threatened species recorded in this area. The collected species $41 \%$ of the total genera and $9 \%$ of the total ginger species of Zingiberaceae in the Philippines. Further, the high endemicity (82\%) of ginger species in this area in the total collected species is also noteworthy and adds feature to Mt. Kitanglad to be declared as a UNESCO World Heritage Site in addition to being an ASEAN Heri- 
tage Park. It is recommended to deeply appreciate the diversity and status of Zingiberaceae in Cinchona Forest Reserve for further investigations. Cinchona Forest Reserve must be preserved and protected, since it is expected that there are still several understudied vascular flora in the area.

\section{Acknowledgment}

The researchers acknowledge Mr. Al Ray Bergado for accompanying the researchers to the site; Mr. Emiliano Lumiston, the officer-in-charge of Cinchona Forest Reserve for allowing us to conduct our research; and to the Department of Environment and Natural Resources (DENR) Region 10, PAMB, PENRO of Malaybalay City of Bukidnon, and Local Government Unit (LGU) officials for allowing us to conduct this study.

\section{References}

1. Lamb A, Gobilik J, Ardiyani M, Poulsen AD (2013) A Guide to Gingers of Borneo. Natural History Publications (Borneo), Kota Kinabalu.

2. Pelser PB, Barcelona JF, Nickrent DL eds. (2011) onwards) Co's Digital Flora of the Philippines. www.philippineplants.org. Accessed date: January, 2020.

3. Bhunia D, Mhondal AK (2012) Antibacterial activity of Alpinia L. (Zingiberaceae) from Santal and Lodha Tribal areas of Paschim Medinipur Districts in Eastern India. Advances in Bioresearch 3 (1): 54-63.

4. Naive MAK, Alejandro GJD (2018) Hornstedtia garbosa (Zingiberaceae: Alpinieae), a new species from Mindanao, Philippines. Phytotaxa 347: 183-188. doi: 10.11646/phytotaxa.347.2.6.

5. Docot RVA, Banag CI, Tandang DN et al. (2019) Recircumscription and revision of the genus Vanoverberghia (Zingiberaceae). Blumea 64 (2): 140-157. doi: 10.3767/blumea.2019.64.02.05.

6. Docot RVA, Banag CI, Poulsen AD (2019) Reinstatement and revision of the genus Adelmeria (Zingiberaceae) endemic to the Philippines. Taxon 68 (30). doi: 10.1002/tax.12071.

7. Docot, RVA, Mendez NP, Domingo CBM (2019) A new species of Hornstedtia and a new species record of Globba (Zingiberaceae) from Palawan, Philippines. Gardens Bulletin Singapore 71 (2): 445 - 457. doi: 10.26492/gbs71(2).2019-13.

8. Acma FM, Mendez NP (2018) Noteworthy records of Philippine endemic gingers (Zingiberaceae) in the buffer zone of Mt. Hamiguitan Range Wildlife Sanctuary, Da- vao Oriental, Philippines. Environmental and Experimental Biology 16 (2): 111-115. doi: 10.22364/eeb.16.10.

9. Tobias AB, Malabrigo PL, Umali AGA et al. (2019) Taxonomy, Recollection and Conservation of newly discovered populations of Hedychium philippinense (Zingiberaceae): an endemic and threatened species in the Philippines. Asian Journal of Conservation Biology 8 (1): 88-92.

10. Acma FM, Mendez NP, Lagunday NE, Amoroso VB (2019) New record of Plagiostachys albiflora Ridl. (Zingiberaceae) in the Philippines. Modern Phytomorphology 13: 5-8.

11. Acma FM (2014) Amomum dealbatum Roxb. (Alpinoideae, Zingiberaceae), a new record for the Philippine flora. Asia Life Sciences 23 (2): 527-536.

12. Kress WJ, Prince LM, Williams KJ (2002) The phylogeny and a new classification of the gingers (Zingiberaceae): evidence from molecular data. American Journal of Botany 89: 1682-1696. doi: 10.3732/ajb.89.10.1682.

13. Harris DJ, Newman MF, Hollingsworth ML et al. (2006) The phylogenetic position of Aulotandra Gagnep. (Zingiberaceae). Nordic Journal of Botany 23 (6): 725-734. doi: 10.1111/j.1756-1051.2003.tb00451.x.

14. Naive MAK (2017) Zingiberaceae of Kalatungan Mountain Range, Bukidnon, Philippines. Bioscience Discovery 8 (3): 311-319.

15. Larsen K, Ibrahim H, Khaw SH, Saw IG (1999) Ginger in Peninsular Malaysia and Singapore. Natural History Publications (Borneo) Kota Kinabalu.

16. Poulsen AD (2006) Etlingera of Borneo. Natural History Publications, Kota Kinabalu.

17. Acero KML, Amoroso VB, Lumista HP et al. (2019) Species Composition and Distribution of Zingiberaceae in Mt. Hamiguitan expansion site, Davao Oriental, Philippines. Journal of Tropical Biology and Conservation 16: 121-136.

18. Department of Environment and Natural Resources (DENR) Administrative Order (2017) Updated National List of Threatened Philippine Plants and their Categories. DAO 2017-11. Quezon City. Retrieved from: https://server2.denr.gov.ph/uploads/rmdd/dao-201711.pdf.

19. de Boer H, Newman MF, Poulsen AD et al. (2018) Convergent morphology in Alpinieae (Zingiberaceae): Recircumscribing Amomum as a monophyletic genus. Taxon 67 (1): 6-36. doi: 10.12705/671.2.

20. Te-Lin W, Larsen K (2000) Zingiberaceae. Flora of China 24: 322-377. 